\title{
Status and relation to inflammation of some serum trace elements (TE) in hemodialysis (HD) patients
}

\author{
Trendafilov $I^{1}$, Georgieva $I^{1}$, Manolov $V^{2}$, Atanasova $B^{2}$, Vasilev $V^{2}$, Arabadjieva $D^{3}$, Velkova $N^{3}, D_{i m i t r o v a ~} V^{3}$ and Yonova $D^{3 *}$ \\ ${ }^{1}$ Dialysis Center, Medical University, Sofia, Bulgaria \\ ${ }^{2}$ Central Clinical Laboratory and Immunology, Medical University, Sofia, Bulgaria \\ ${ }^{3}$ Nephrology Department, Medical University Hospital “Lozenetz”, Bulgaria
}

\begin{abstract}
Introduction: Abnormal blood levels of various trace elements have not been consistently studied in the end-stage renal disease. The uremic patients treated by chronic dialysis lose one important route of trace elements excretion and are exposed to an artificial environment of the dialysis fluid. The process may lead to depletion of biologically essential substances or its accumulation in the patient. Thus, dialysis patients are at risk for both deficiency and accumulation of trace elements, depending on dietary intake, residual kidney function and removal by dialysis.
\end{abstract}

Aim of the study: The present study was pointed to investigate possible existence of trace elements disturbances in uremic patients undergoing regular hemodialysis (HD) treatment and its relationship to some inflammatory markers.

Material and methods: Blood samples of 56 patients on hemodialysis and 30 healthy controls were analysed twice in 3 months follow up period for quantitation of serum zinc, selenium and copper, serum albumins - transporters of the TE in the human body, and C-reactive protein (CRP) and interleukine-6 (Il-6) - two important markers of inflammation.

Results: The study revealed that serum zinc and selenium concentrations in HD patients are distinctly decreased compared to that of healthy controls, and serum copper was found slightly abnormally increased. Significant negative correlation was found between $\mathrm{Zn} / \mathrm{CRP}$ and $\mathrm{Zn} / \mathrm{Il}-6$ and positive one - between $\mathrm{Cu} / \mathrm{CRP}$ and $\mathrm{Cu} / \mathrm{Il}-6$.

Conclusion: Disturbances of trace elements are primarily the result of renal failure, but they may be further exacerbated by the dialysis procedure. Negative correlations between $\mathrm{Zn}$ and some inflammatory markers and positive - between them and $\mathrm{Cu}$, probably suggest some influence of these TE on the inflammatory process in dialysis patients.

\section{Introduction}

Trace elements are natural, essential, homogenous, inorganic substances which are taken with food or drink present in minor amounts in the human body, but also have a unique role in a number of important structures and processes. Determining the status of trace elements is difficult and requires specialized equipment (an Atomic Absorption Spectrophotometer) [1-3].

Precision of serum levels of trace elements is complicated in a number of diseases that attack the quantitative and/or qualitative serum binding proteins, transporting trace elements (which are mostly albumins) to target organs and tissues [1,3-5]. Changes in the levels of trace elements in chronic kidney diseases (CKD) are not well understood, but it is essential to establish the status of those, associated with the functions of the organs that are damaged in the disease $[5,6]$. Therefore, the studies conducted to date in CKD have focused on the trace elements $\mathrm{Zn}$, Se, and $\mathrm{Cu}$. Most authors found deficient zinc ( $\mathrm{Zn})$ [5-8] and selenium (Se) [9-12], and moderate excess of copper $(\mathrm{Cu})$ $[7,13,14]$. Single messages do not find abnormal TE blood levels, or don't accept the existence of deficiencies and explain lower serum levels of these trace elements due to their abnormal redistribution in the tissues. Hemodialysis (HD) removes uremic toxins by equilibration of plasma and dialysate across a semipermeable membrane $[1,4,11,15]$. Substances with lower concentrations in dialysate than in blood tend to be removed by dialysis $[12,16,17]$. The process may lead to depletion of biologically essential substances as well. Substances present in dialysate but not in blood will accumulate in the patient, and the lack of renal clearance in hemodialysis patients might lead to toxicity of trace elements ingested with the food, even when they are not present in dialysate. Thus, hemodialysis patients are at risk for both deficiency and accumulation of trace elements, depending on dietary intake, residual kidney function and removal by dialysis $[17,18]$. Most studies to date demonstrated significantly altered blood levels of trace elements in ESRD patients compared to healthy controls $[1,2,4,6,19,20]$. In view of the growing interest in certain essential trace elements in CKD, especially in patients on dialysis, we set the aim to determine serum levels of $\mathrm{Zn}$, Se and $\mathrm{Cu}$ in patients on hemodialysis, their ratios as well as their relation to $\mathrm{C}$-reactive protein (CRP) - one of the most

${ }^{\star}$ Correspondence to: Yonova D, Nephrology Department, Medical University Hospital “Lozenetz", Bulgaria, E-mail: yonovad@abv.bg

Key words: Chronic kidney disease (CKD), Chronic renal failure (CRF), Zinc $(\mathrm{Zn})$, Selenium (Se), Copper (Cu), C-reactive protein (CRP), Interleukin-6 (Il-6), Hemodialysis (HD)

Received: December 10, 2018; Accepted: December 28, 2018; Published: December 31, 2018 
sensitive markers of inflammation, evaluating the consequences of these pathological deviations.

\section{Material and methods}

A total of 86 subjects were included in the study. Out of these 56 were hemodialysis patients ( $1^{\text {st }}$ group $)$ and 30 were healthy controls $\left(2^{\text {nd }}\right.$ group).

\section{Inclusion criteria}

Healthy controls: Twenty healthy volunteers were selected and matched for age, sex and social background. Only those who proved to be in a good state of health and free from any signs of chronic diseases were included. Study group subjects: chronic kidney disease (CKD) patients in the age group of 32 to 67 years, undergoing hemodialysis more than 3 months, were selected.

The patients were diagnosed on the basis of detailed clinical history, examination, and other relevant biochemical investigations. All patients had on four hours dialysis sessions with polysulphone dialysis membranes.

\section{Exclusion criteria}

The patients suffering from other diseases: diabetes, inflammatory diseases, hepatic diseases, respiratory diseases, oncological diseases as well as smokers and alcoholics were excluded from the study.

Informed consent was obtained from each participant in the study.

The study was approved by Institutional Ethical Committee.

The blood was collected at fasting time for all participants, before hemodialysis from each patient and, in the morning from the controls. Serum samples were diluted with deionized water and $\mathrm{Zn}$, Se and $\mathrm{Cu}$ levels were then measured on an atomic absorption spectrophotometer. The concentrations of $\mathrm{Zn}$, Se and $\mathrm{Cu}$ in serum were reported as $\mu \mathrm{mol} / \mathrm{l}$ and $\mathrm{nmol} / \mathrm{l}$ after necessary corrections were made. The values are expressed as mean $\pm \mathrm{SD}$. Student's't' test was done for comparison of data.

\section{Results}

The mean levels of $\mathrm{Zn}$, Se, Cu; serum albumins (Alb), Il-6 and CRP in the two groups are presented in the next Table 1, Figures 1-3.

We have found the next correlations between the investigated trace elements $\mathrm{Zn}, \mathrm{Se}, \mathrm{Cu}$ and between them and: Albumins, Il-6 and: C-reactive protein, in group 1 (HD pts.):

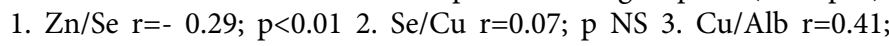
$\mathrm{p}<0.014 . \mathrm{Zn} / \mathrm{Cu} \mathrm{r}=-0.21 ; \mathrm{p}<0.05$ 5. Se/CRP r=0.10; p NS 6. Cu/CRP $\mathrm{r}=0.28 ; \mathrm{p}<0.057 . \mathrm{Zn} / \mathrm{Alb} \mathrm{r}=0.43 \mathrm{p}<0.01$ 8. Se/Alb $\mathrm{r}=0.34 ; \mathrm{p}<0.059 . \mathrm{Cu} /$ Il-6 r=0.27; $\mathrm{p}<0.05$ 10. Zn/Il-6 r= $-0.25 ; \mathrm{p}<0.0511$. Se/Il-6 r=-0.16; $\mathrm{p}$ NS 12. $\mathrm{Zn} / \mathrm{CRP} \mathrm{r}=-0.53 ; \mathrm{p}<0.001$

The correlations between the TE and with TE and C-reactive protein in the group of patients on HD (group 1) are shown at the next Figure 4 and 5.

\section{Discussion and Conclusion}

$\mathrm{Zn}$ is an essential trace element, mandatory for mobilization of vitamin A from the liver and is involved in the construction and the function of more than 200 metalloenzymes, relating to synthesis and metabolism of proteins, DNA and RNA $[7,18,20]$. More than $90 \%$ of the enzyme $\mathrm{Zn}$ is in erythrocyte's carboanhydrase. Various aspects of

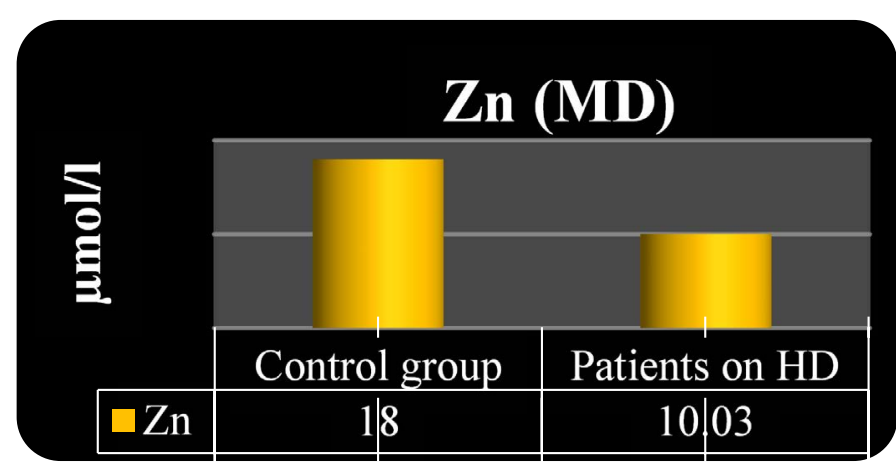

Figure 1. Serum $\mathrm{Zn}$ in the both groups

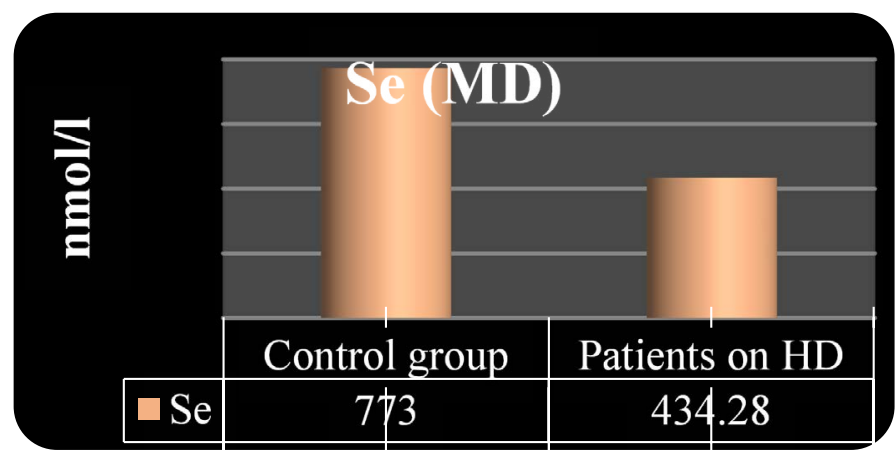

Figure 2. Serum Se in the both groups

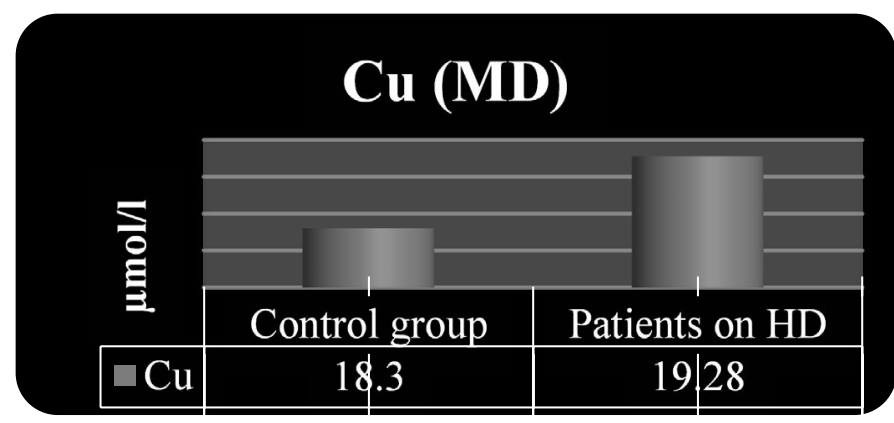

Figure 3. Serum $\mathrm{Cu}$ in the both groups of the study

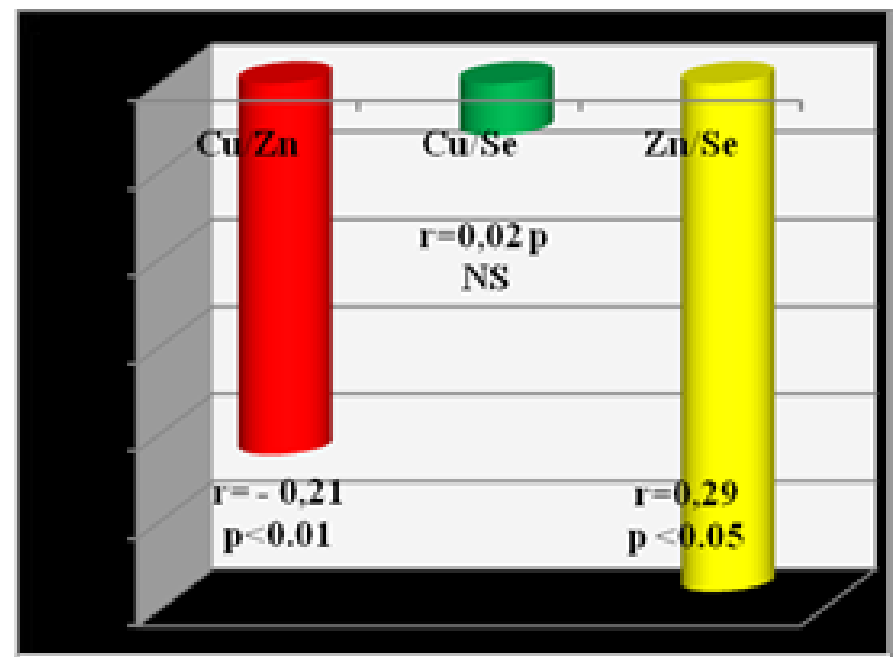

Figure 4. Correlations between $\mathrm{Cu}, \mathrm{Se}, \mathrm{Zn}$ in group 1-patients on $\mathrm{HD}$ 
Table 1. $\mathrm{MD} \pm \mathrm{SD}$ of serum levels of $\mathrm{Zn}, \mathrm{Se}, \mathrm{Cu}$, Albumins, $\mathrm{CRP}$ and Il- 6 in the groups of the study

\begin{tabular}{|c|c|c|c|c|c|c|}
\hline Group No & $\frac{\mathrm{Zn}}{\mathrm{MD} \pm \mathrm{SD}(\mu \mathrm{mol} / \mathrm{l})}$ & $\begin{array}{c}\mathrm{Se} \\
\mathrm{MD} \pm \mathrm{SD} \\
(\mathrm{nmol} / \mathrm{l})\end{array}$ & $\begin{array}{c}\mathrm{Cu} \\
\mathrm{MD} \pm \mathrm{SD}(\mu \mathrm{mol} / \mathrm{l})\end{array}$ & $\begin{array}{c}\text { Alb } \\
\mathrm{MD} \pm \mathrm{SD}(\mathrm{G} / \mathrm{l})\end{array}$ & $\begin{array}{c}\mathrm{CRP} \\
\mathrm{MD} \pm \mathrm{SD} \\
(\mathrm{mg} / \mathrm{l})\end{array}$ & $\begin{array}{c}\mathrm{Il}-6 \\
\mathrm{MD} \pm \mathrm{SD} \\
\mathrm{pg} / \mathrm{ml}\end{array}$ \\
\hline $\begin{array}{l}1^{\text {st }} \text { group } \\
56 \text { HD pts. }\end{array}$ & $\begin{array}{l}1^{\text {st }} \mathrm{m} .10 .3 \pm 1.8 \\
3^{\text {rd }} \text { m. } 10.1 \pm 1.5\end{array}$ & $\begin{array}{l}434.2 \pm 117.8 \\
453.1 \pm 123.6\end{array}$ & $\begin{array}{l}19.3 \pm 4.9 \\
21.2 \pm 2.8\end{array}$ & $\begin{array}{l}36.3 \pm 8.9 \\
35.8 \pm 8.3\end{array}$ & $\begin{array}{l}4.02 \pm 1.0 \\
6.01 \pm 0.9\end{array}$ & $\begin{array}{l}8.4 \pm 2.4 \\
9.1 \pm 1.4\end{array}$ \\
\hline $\begin{array}{l}2^{\text {nd }} \text { group } \\
30 \text { controls }\end{array}$ & $\begin{array}{l}1^{\text {st }} \mathrm{m} .18 .2 \pm 1.9 \\
3^{\text {rd }} \mathrm{m} \cdot 16.9 \pm 1.5\end{array}$ & $\begin{array}{l}773.5 \pm 124.6 \\
804.4 \pm 133.1\end{array}$ & $\begin{array}{l}18.3 \pm 5.2 \\
19.8 \pm 3.6\end{array}$ & $\begin{array}{l}46.9 \pm 3.6 \\
47.3 \pm 2.8\end{array}$ & $\begin{array}{l}1.39 \pm 2.0 \\
1.45 \pm 1.5\end{array}$ & $\begin{array}{l}3.1 \pm 1.5 \\
2.3 \pm 1.2\end{array}$ \\
\hline $\begin{array}{l}1^{\text {st }} \text { month } \\
3^{\text {rd }} \text { month }\end{array}$ & $\begin{array}{l}\mathrm{P}<0.001 \\
\mathrm{P}<0.001\end{array}$ & $\begin{array}{l}\mathrm{P}<0.001 \\
\mathrm{P}<0.001\end{array}$ & $\begin{array}{l}\text { P NS } \\
\text { P NS }\end{array}$ & $\begin{array}{l}\mathrm{P}<0.01 \\
\mathrm{P}<0.01\end{array}$ & $\begin{array}{l}\mathrm{P}<0.01 \\
\mathrm{P}<0.01\end{array}$ & $\mathrm{P}<0.001 \mathrm{P}<0.001$ \\
\hline
\end{tabular}

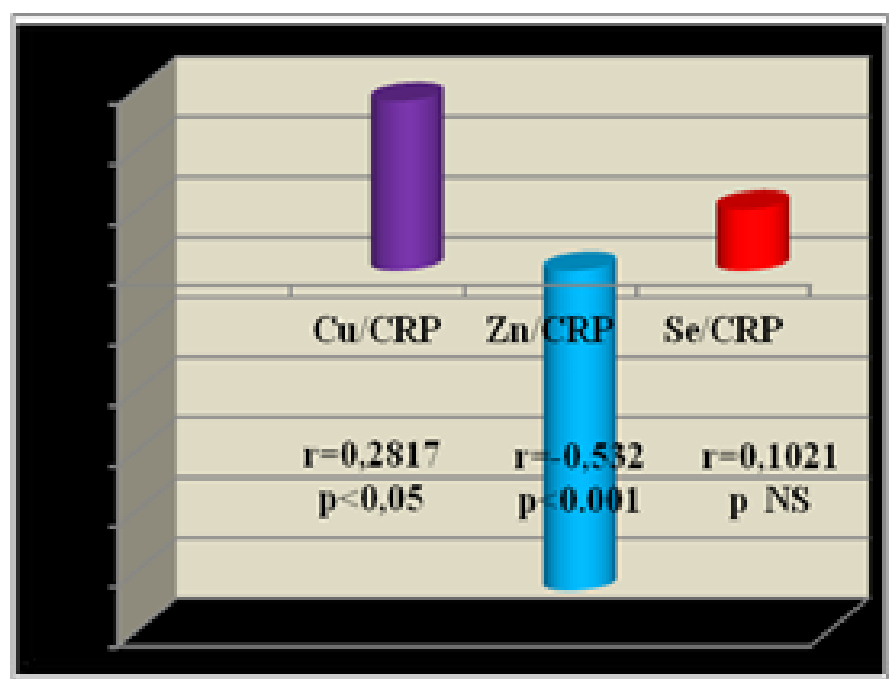

Figure 5. Correlations between TE \& CRP in group 1-patients on HD

disorders of plasma $\mathrm{Zn}$ in patients with CKD on hemodialysis treatment are described in the medical literature $[7,13,18,20]$. Pathophysiology of $\mathrm{CKD}$ and the nature of hemodialysis are obviously related to damage of the mineral and trace elements metabolism of these patients. The main causes of abnormal lower plasma $\mathrm{Zn}$ in patients with $\mathrm{CKD}$ and on HD are as follows [1,2,6,18]: a). Reduced intake of food, due to anorexia or dietary restriction; b). HD procedure "per se" is another factor, causing $\mathrm{Zn}$ deficit (acting to eliminate or conserve serum trace elements); c). Redistribution of $\mathrm{Zn}$ from plasma to other tissues due to increased expression of some transport proteins in presence of chronic inflammation and CRF; d). Deficit of iron (Fe) could cause $\mathrm{Zn}$ blockade in erythrocytes; e). Decreased gastrointestinal absorption of $\mathrm{Zn}$ - in uremia it is due to uremic intoxication and deficit of calcitriol; f). The competition between $\mathrm{Zn}$ and $\mathrm{Cu}$ for their common transporter metalothionine, as its affinity is higher for $\mathrm{Cu}$ and the last has usually higher plasma level in CRF and HD; g). Decreased natural plasma protein binders of $\mathrm{Zn}$

Se is an essential component of the enzymes, named glutathione peroxidases (GSH-Px), a part of natural defense system against oxidative stress, as of some other selenoenzymes, acting in immunity, human growth and a number of important vital processes $[9,10,15,16]$. GSH-Px is the most extensively characterized selenoprotein, being found in Red Blood Cells (RBC) and cytosol of nearly all tissues of mammals, birds and several other organisms [10,17]. It is called classical GSH-Px (cGSH-Px or GSH-Px1). Five isoforms of GSH-Px have been identified, two are present in the blood: GSH-Px 1 presents in red blood cells and GSHPx 3 presents in plasma (important fact is that it's produced in the kidneys). Both have a tetrameric form and contain one selenium per subunit $[10,15,16]$.
Symptoms of Se deficiency include cardiomyopathy, muscle degeneration, hepatocyte necrosis, pancreatic degeneration, growth retardation, reproductive disorders.

Possible mechanisms for the occurrence and deepening of Se deficiency in CKD patients are described as follows [9,11,17]: a). Reduced intake of food, due to anorexia or dietary restriction; b). The HD procedure "per se" is another factor, causing Se deficit (eliminating it during HD); c). Decreased natural plasma protein binders of Se. d). Redistribution of Se from plasma to other tissues due to increased expression of some transport proteins in presence of chronic inflammation and CRF.

$\mathrm{Cu}$ is involved in the structure and function of a number of enzymes, acting in the erythropoiesis, immune system, skeletal integrity, collagen formation, support of the myelin sheaths of neurofibrils, melanin and other pigments synthesis $[1,3,14]$. Copper is an integral component of many metalloenzymes and is involved in many biological processes. Copper and iron can catalyze the formation of reactive oxygen species via Haber-Weiss and Fenton-like reactions and lead to the oxidative damage of the cells. $\mathrm{Zn}$ and $\mathrm{Cu}$ are involved in enzyme superoxyd dismutase (SOD) $[2,3,7,13]$. $\mathrm{Cu}$ is a component of a few other enzymes, like ceruloplasmin and cytochrome oxidase $[5,14]$. Cytochrome oxidase plays an essential role in cellular energy. As catalyzing the reduction of molecular oxygen $(\mathrm{O} 2)$ to water $(\mathrm{H} 2 \mathrm{O})$, cytochrome oxidase generates an electrical gradient, which is used by mitochondria to create vital energy for the organism and stored in molecules of ATP. Two coppercontaining enzymes, ceruloplasmin (feroxidase I) and (feroxidase II) have the ability to oxidize iron $(\mathrm{Fe} 2+)$ to iron $(\mathrm{Fe} 3+)$, which are connected to the protein transferrin for transportation to the red blood cells and blood formation $[6,7,14]$.

$\mathrm{Cu}$ deficit leads to increased production of free radical species and lipid peroxidation $[8,12]$.

Excess $\mathrm{Cu}$ builds up in the soft tissues of liver and disrupt the liver's metabolic abilities to detoxify the blood. Cu toxicity is disrupting to the liver's glucoronidation pathway, that helps to eliminate estrogens by making them water soluble. When $\mathrm{Zn}$ gets displaced by $\mathrm{Cu}$, metalothionine (the main heavy metal binding protein) production falls dramatically; glutathione (the main antioxidant of the body) also declines when too much $\mathrm{Cu}$ gets in the liver tissues [12,14]. $\mathrm{Cu}$ is very stimulating to the nervous system. It increases epinephrine, norepinephrine and dopamine and decreases histamine. These effects can give rise of many psychological imbalances - swings, depression, agitation, anxiety etc [21].

We found that hemodialysis patients appear to have lower levels of $\mathrm{Zn}$ and Se than people in the general population. $\mathrm{Zn}$ deficiency is associated with delayed wound healing, and immune deficiency, characterized by impaired cell proliferation, abnormal T-cell function, defective phagocytosis, and abnormal cytokine expression, which might contribute to the excess risk of infection observed in $\mathrm{HD}$ 
patients $[1,4,7,18,20]$. Zn deficiency may also cause or contribute to a number of relatively non-specific conditions commonly observed in HD patients, including anorexia, dysgeusia, and impaired cognitive function $[2,6,18,19]$. Although the biological significance of low blood Se concentrations is less clear, severe selenium deficiency leads to sudden death and cardiomyopathy in the general population $[9,11,19]$. Lower levels of serum Se without severe deficiency have been associated with hypertension, heart failure, and coronary disease in the general population [19], and with cardiomyopathy among dialysis patients $[1,2,15,16]$. Finally, mild Se deficiency appears to increase susceptibility to oxidative stress $[8,9,10,12]$, which may be relevant to HD patients in whom oxidative stress is markedly increased [12].

For most of the TE studied, the biological significance of higher blood levels is unclear. Our study found not significantly higher than normal levels of $\mathrm{Cu}$ in the group of $\mathrm{HD}$ patients, without any prominent symptoms; that is why do not to discuss it. Correlations, we found between the investigated TE in HD patients suggest, that Se and $\mathrm{Cu}$ are not in a significant correlation, perhaps because they are not involved together in close structures and functions in the human body in ESRD, but $\mathrm{Zn}$ and $\mathrm{Se}$ are in a mild positive relation $(\mathrm{r}=0.29 ; \mathrm{p}<0.01)$, probably because they both participate in some enzyme structures. Negative correlation of $\mathrm{Zn}$ and $\mathrm{Cu}(\mathrm{p}<0.05)$ proved the antagonism between these TE. Positive correlation of CRP and Il- 6 with $\mathrm{Cu}$ and negative - with $\mathrm{Zn}$ showed that $\mathrm{Cu}$ has saved its pro- and $\mathrm{Zn}$ - its antiinflammatory effect even in CRF and HD status.

In summary, we found that blood concentrations of some biologically important trace elements were substantially different in HD patients, then in healthy controls. Since both deficiency and excess of TE are potentially amenable to therapy, trace element status appears worthy of investigation $[22,23]$.

Our data suggest that our next aim should be to investigate the link between $\mathrm{Zn}$ and Se status, and clinical outcomes in dialysis patients, in whom the risk of infection is dramatically elevated, compared to people with normal kidney function, and to supplement the deficits.

\section{Conflicts of interest}

The authors declare that there is no conflict of interest regarding the publication of this paper.

\section{Acknowledgments}

The study is a part of a scientific 2 years long project, with chief researcher prof. D. Yonova (named "Serum levels of hepcidine, $\mathrm{Zn}, \mathrm{Se}$, $\mathrm{Cu}, \mathrm{Mg}$ and their relationships with anaemia and oxidative stress in ESRD on conservative or dialysis treatment"), granted in 2016 year by Medical University, Sofia, Bulgaria.

\section{References}

1. Ramprasad N, Al-Ghonaim Mohammed I (2013) Role of trace elements and lipid peroxidation levels in pre and post hemodialysis of chronic renal failure patients. Int $J$ of Res in Biochem and Biophys 3: 1-6.

2. Balla SEEH, Ismail AM (2016) Impact of hemodialysis on serum zinc and copper level in CKD patients. J Appl Pharm Sci 6: 165-168.
3. Kiziltas H, Ekin S, Erkoc R (2008) Trace element status of chronic renal patients undergoing hemodialysis. Bio Trace Elem Res 124: 103-109.

4. Tonelli M, Weibe N, Hemmelgarn B, Klarenbach S, Field K, et al. (2009) Trace elements in hemodialysis patients: a systematic review and meta - analysis. $B M C$ medicine 7: 25 .

5. Shouman MG, Ibrahim HY, Salama EEE, ElKhayat Z, Ashour M (2009) Trace elements in pediatric hemodialysis patients. Int Res J Med Med Sci 4: 435-440.

6. Hasanato RM (2014) Assessment of trace elements in sera of patients undergoing renal dialysis. Saudi Med J 35: 365-370.

7. Batista MN, Cuppari L, de Fatima Campos Pedrosa L, Almeida MdG, de Almeida JB et al. (2006) Effect of endstage renal disease and diabetes on zinc and copper status. Biol Trace Elem Res 112: 1-12.

8. Manolov V, Yonova D, Atanasova B, Velizarova M, Vasilev V, et al. (2014) Anemia in chronic dialysis patients - the right therapeutic choice? Int Res J Med Med Sci 2: 270-273.

9. Burk RF, Hill KE, Motley AK (2016) Comparative study on trace element excretions between nonanuric and anuric patients undergoing continuous ambulatory peritoneal dialysis. Nutrients 8: 826 .

10. Gómez de Oña C, Martínez-Morillo E, González EG, Argüelles PV, Merayo CF, et al (2016) Variation of trace element concentrations in patients undergoing hemodialysis in the north of Spain. Scand J Clin Lab Invest 76: 492-499.

11. Wlodarczyk Z, Zachara BA, Masztalerz M, Wasowicz W, Gromadzinska J (2005) Influence of selenium supplementation to renal allograft recipients on plasma glutathione peroxidase activity. Trace Elem Electrolytes 22: 16-22.

12. Yonova D, Trendafilov I, Papazov V, Stanchev I, Zidarov R, et al. (2004) Comparative study of oxidative stress in peritoneal dialysis and hemodialysis patients. Hippokratia 8: $170-172$.

13. Balla SHE, Ismail AM (2016) Impact of hemodialysis on serum Zinc and Copper level in CKD patients. $J$ of Appl Pharmac Sci 6: 165-168.

14. Angelova M, Asenova S, Nedkova V, Koleva-Kolarova R (2011) Copper in the human organism. Trakia Journal of Sciences 9: 88-98.

15. Tonelli M, Wiebe N, Bello A, Field CJ, Gill JC, et al. (2017) Concentrations of trace elements in hemodialysis patients: A prospective cohort study. AJKD 705: 696-704.

16. Zachara BA, Gromadzinska J, Wasowicz W, Zbrog Z (2006) Red blood cell and plasma glutathione peroxidase activities and selenium concentration in patients with chronic kidney disease; a review. Acta Biochem Pol 53: 663-677.

17. Boosalis MG (2008) The role of selenium in chronic disease. Nutr Clin Pract 23: 152160. [Crossref]

18. Roozbeh J, Sharifian M, Sagheb MM, Shabani S, Hamidian Jahromi A, et al. (2011) Comment on: does zinc supplementation affect inflammatory markers in hemodialysis patients? Am J Clin Nutr 67: 965-971.

19. Liakopoulos V, Roumeliotis S, Gorny X, Eleftheriadis T, Mertens PR (2017) Oxidative stress in patients undergoing peritoneal dialysis: A current review of the literature. Oxid Med Cell Longev 2017: 14.

20. Neto LC, Bacci MR, Sverzutt LC, Costa MG, Alves BC, et al. (2016) The role of zinc in chronic kidney disease patients on hemodialysis: A systematic review. Health 8: 344-352.

21. Mano M (2014) Abnormal Copper homeostasis: Mechanisms and roles in neurodegeneration. Toxics 2: 327-345.

22. Gómez de Oña C, Martínez-Morillo E, González GE, Argüelles VP, Merayo FC, et al (2016) Variation of TE concentrations in patients undergoing HD in the north of Spain. Scand J Clin Lab Invest 76: 492-499

23. Tonelli M, Wiebe N, Bello A, Field CJ, Gill JS, et al. (2018) Concentrations of trace elements and clinical outcomes in HD Patients. CJASN 13: 907-915.

Copyright: (C2018 Trendafilov I. This is an open-access article distributed under the terms of the Creative Commons Attribution License, which permits unrestricted use, distribution, and reproduction in any medium, provided the original author and source are credited. 